\title{
Dental Neglect among Children and Their Parents in District Panchkula
}

INTRODUCTION: Dental caries is one of the most prevalent chronic diseases treatment of which is being highly neglected especially in children. Dental Neglect (DN) is persistent failure to meet a child's basic oral health needs, likely to result in serious impairment of the child's general health and development. Dental Neglect scale appears to be an appropriate method for objectifying dental neglect.

AIM: To evaluate the relationship between dental neglect, dental caries and socio-economic status in 3 to 15 years old children. MATERIALS AND METHOD: The sample consisted of fifty parent children dyads, parents were asked to fill the questionnaires assessing their dental neglect and socio-economic status. Caries were assessed using the WHO criteria (2013). RESULTS: Study showed that a greater dental neglect score (21.16) was reported among children belonging to low socioeconomic status. A higher DMFT (2.08) and DMFS (3.0) scores were found to be significantly associated with higher DN. CONCLUSION: The socio-economic status plays an important role in the parent's knowledge and attitude regarding the dental care of their child.

KEYWORDS: Dental Neglect, Dental caries, Socio-economic status.

\section{INTRODUCTION}

The United Nations Convention on the Rights of the Child, ratified by all countries other than Somalia and the United States of America (USA), states that children have a right to be protected from all forms of negligent treatment, and enjoy the highest attainable standards of health. In addition, the UK government has identified the key outcomes, which matter most to children, including being healthy and staying safe (i.e. being protected from harm and neglect). Neglect is the most common among parents, and is recorded in $44 \%$ of all children on child protection registers or the subjects of child protection plans in the UK and $78.3 \%$ in the USA.

Radford and co-workers reported that one in 20 (5\%) children under 11 have been neglected at some point, and one in $30(3.7 \%)$ have been severely neglected. Furthermore, almost one in 10 young adults $(9 \%)$ report a history of severe neglect by parents or guardians during childhood. ${ }^{1}$ Dental caries is most common diseases of childhood worldwide. In the USA, it is five times more common than asthma. Educating parents and children in how to prevent dental disease is an essential part of any course of dental treatment. However, recently the dentist's in the UK have begun to understand fully the conservative implications of untreated dental disease. ${ }^{2}$

Dental neglect among parents can be assessed using a scale called Dental Neglect Scale (DNS). The Dental Neglect Scale (DNS) assesses the extent to which an individual cares for his/her teeth, receives professional dental care, and believes oral health to be important. It was originally composed of 7 items and developed for parents, who were directed to rate their child's behaviors and attitude towards oral health. Children whose parents rated them as having higher dental neglect had more caries and were less likely to have gone to a dentist in the previous two years than were children whose parents rated them has having less neglect. ${ }^{3}$

Dental neglect is defined by the American Academy of Pediatric Dentistry (AAPD) as failure of caregivers to provide prerequisites of proper oral function via seeking and timely dental treatment services necessary to be free from pain and infec $\neg$ tion. The victims often demonstrate changes in behavior. However it is likely that child dental neglect represents an isolation problem; it is known that it may be a suitable indicator of 
other types of neglect. ${ }^{4}$

The dental treatment is still a night mare for most of the people. Dental neglect have tight bond with dental caries. If left untreated, dental problems can lead to pain, infection and loss of functions. These outcomes can adversely affect learning, communications, nutrition and other activities necessary for normal growth and development. Factors such as family isolation, lack of finance, parental ignorance, or lack of perceived value of oral health may cause failure to receive dental treatment. ${ }^{5}$

Prevention is the better option than cure. People need to be very much attentive and meticulous to maintain oral health for the prevention of oral disease. Prevention of oral disease is very effective, efficient, adequate and acceptable habit to have better oral health. Dental professionals and audio visual media provide the necessary dental care measures. But, the truth is that a very few people take adequate regular home dental care and do not take periodic/yearly dental check up by dental professionals to keep their oral cavity healthy. ${ }^{6}$

It is the responsibility of parents to pursue healthrelated necessities of their children. In this regard, the lack of parent's or guardian's attention will have a negative influence on the child's oral status. Assessing the dental neglect among children would help the clinician to identify the specific reason for the failure to prevent and treat dental caries. ${ }^{7}$

Children are dependent on their parents/caregivers to maintain their oral health which includes managing oral hygiene and diet, and seeking treatment when needed. If dental caries are not treated on time they can have an adverse impact on the health, wellbeing, and quality of life of the child. Severe consequences of untreated dental diseases include pain, sleep deprivation, interference with performance at school and social activities. Dental neglect is the willful or persistent failure to meet a child's basic oral health needs by not seeking or following through with necessary treatment to ensure a level of oral health that allows function and oral health. The dental neglect scale (DNS) appears to be an appropriate method for objectifying dental neglect. DNS for children assesses the extent to which a parent or caretaker cares for the child's teeth, receives professional dental care, and believes oral health to be important Hence, DNS helps to identify the reason for poor oral health in children

\section{AIM AND OBJECTIVES}

Aim: The aim of the study was to evaluate the dental neglect among children in district Panchkula and its association with the dental caries in children aged 3-15 years.

\section{Objectives:}

- To evaluate the association between the dental caries and dental neglect among parents of children aged 3-15 years.

- To evaluate the association of dental neglect with the socioeconomic status of the family.

\section{MATERIAL AND METHODOLOGY}

The participants included 50 children aged from 3 to 15 years, and the questionnaire was answered by their parents. An informed consent was obtained from the participating parents. The parents were asked to fill in a comprehensive questionnaire which included demographic details (Kuppuswamy scale 2016) and seven questions of DNS (Thomson et al., 1996). Proforma was prepared to collect the data about the dental neglect. Proforma contained a comprehensive questionnaire in which dental neglect was investigated by capturing parental responses to seven statements, using a Likert scale ranged from one ("definitely no") to five ("definitely yes") the statements were:

1. Your child maintains his/her home dental care. 2. Your child receives the dental care he/she should.

3. Your child need dental care, but you put it off. 4. Your child needs dental care but he/she put it off.

5. Your child brushes as well as he/she should.

6 . Your child control meals snacking as well as he/she should.

7. Your child considers his/her dental health to be important.

Children with the consent from parents to participate in the survey were examined. Oral 
examination of children was conducted using disposable mouth mirror and blunt ball-ended probe $(0.5 \mathrm{~mm})$ in natural day light. Dental caries status was assessed by the WHO criteria.

\section{RESULTS}

Out of the total sample of 50 students $76 \%$ were males and $24 \%$ were females. The mean age of children was 8.88 . Out of the total population $40 \%$ comprised of lower middle class category, 34\% were in upper middle class category, 30\% were in upper lower class and $6 \%$ comprised of upper class population. (Table-1)

Out of 50 children, a total of $22 \%$ parents answered that their children did maintain their home dental care, $10 \%$ children definitely received the dental care they should achieve, $4 \%$ children required dental care but parent puts it off, $12 \%$ need dental care but put it off themselves, $28 \%$ children brush their teeth properly as they should, $6 \%$ children control the snacking as they should and $22 \%$ children consider their dental health to be definitely important. (Table-2)

The mean dental neglect score was found to be 21.16 and was found to be significantly associated with the SES with the p value of o.03.(Table-3,4)
The mean DMFT and DMFS score was 2.08 and 3.0 respectively and it was also found to be significantly associated with DNS with $\mathrm{p}$ values of 0.01 and 0.006 respectively. (Table-5)

\section{DISCUSSION}

Our study showed that a greater dental neglect score (21.16) was reported among children belonging to low socio-economic status. Similar results were found by Silver $\mathrm{DH}$ et al., 1987, Gurunathan D et al., 2017.7,8 The reason concluded was high cost of dental treatment which is unaffordable by low socioeconomic strata. On the contrary, Al Gahnim et al.,1998 ${ }^{9}$ stated that income does not play a role in attitude towards the oral health.

In our study, mothers who went till high school and fathers who have done post- high school diploma had positive co-relation with the dental neglect. Similar results were found by Freeman et al., 1997, Williams et al., 2002 and Gurunathan D et al., (2016).7,10,11,7

A higher DMFT (2.08) and DMFS (3.0) scores were found to be significantly associated with higher DN. Thomson WL et al., (1996) $)^{12}$ and Ajagannanavar S L et al., (2014) ${ }^{13}$ had similar findings.

\begin{tabular}{|c|c|c|}
\hline \multicolumn{2}{|c|}{ GENDER DISTRIBUTION } \\
\hline Variable & Frequency & $\begin{array}{c}\text { Valid } \\
\text { Percent }\end{array}$ \\
\hline Male & 38 & $76.0 \%$ \\
\hline Female & 12 & $24.0 \%$ \\
\hline Total & 50 & $100.0 \%$ \\
\hline SOCIOECONOMIC STATUS DISTRIBUTION \\
\hline $\begin{array}{c}\text { Upper lower class (5- } \\
\text { 10) }\end{array}$ & 8 & $30 \%$ \\
\hline $\begin{array}{c}\text { Lower middle class } \\
(11-15)\end{array}$ & 20 & $40 \%$ \\
\hline $\begin{array}{c}\text { Upper middle class } \\
(16-25)\end{array}$ & 19 & $34 \%$ \\
\hline $\begin{array}{c}\text { Upper class( 29 and } \\
\text { above) }\end{array}$ & 3 & $6.0 \%$ \\
\hline \begin{tabular}{c} 
Total \\
\hline
\end{tabular} & 50 & $100 \%$ \\
\hline
\end{tabular}

Table 1. Frequency distribution of demographic variables 


\begin{tabular}{|c|c|c|c|c|c|}
\hline Item & $\begin{array}{l}\text { Definitely No } \\
\text { N (\%) }\end{array}$ & $\begin{array}{l}\text { Somewhat } \\
\text { No } \\
\text { N }(\%)\end{array}$ & $\begin{array}{l}\text { Neutral } \\
\mathbf{N}(\%)\end{array}$ & $\begin{array}{l}\text { Somewhat } \\
\text { Yes } \\
\text { N }(\%)\end{array}$ & $\begin{array}{l}\text { Definitely Yes } \\
\text { N (\%) }\end{array}$ \\
\hline $\begin{array}{l}\text { Your child maintains his/her } \\
\text { home dental care }\end{array}$ & $3(6 \%)$ & $17(34 \%)$ & $4(8 \%)$ & $15(30 \%)$ & $11(22 \%)$ \\
\hline $\begin{array}{l}\text { Your child receives the dental } \\
\text { care he/she should }\end{array}$ & $2(4 \%)$ & $4(8 \%)$ & $23(46 \%)$ & $16(32 \%)$ & $5(10 \%)$ \\
\hline $\begin{array}{l}\text { Your child needs dental care, } \\
\text { but you put it off }\end{array}$ & $17(34 \%)$ & $13(26 \%)$ & $9(18 \%)$ & $9(18 \%)$ & $2(4 \%)$ \\
\hline $\begin{array}{l}\text { Your child needs dental care, } \\
\text { but he/she puts it off }\end{array}$ & $4(8 \%)$ & $14(28 \%)$ & $9(18 \%)$ & $17(34 \%)$ & $6(12 \%)$ \\
\hline $\begin{array}{l}\text { Your child brushes as well as } \\
\text { he/she should }\end{array}$ & $\mathrm{o}(\mathrm{o} \%)$ & $16(32 \%)$ & $1(2 \%)$ & $19(38 \%)$ & $14(28 \%)$ \\
\hline $\begin{array}{l}\text { Your child controls between } \\
\text { meal snacking as well as } \\
\text { he/she should }\end{array}$ & $8(16 \%)$ & $23(46 \%)$ & $8(16 \%)$ & $8(16 \%)$ & $3(6 \%)$ \\
\hline $\begin{array}{l}\text { Your child considers his/her } \\
\text { dental health to be important }\end{array}$ & $15(30 \%)$ & $14(28 \%)$ & $3(6 \%)$ & $7(14 \%)$ & $11(22 \%)$ \\
\hline
\end{tabular}

Table 2. Frequency distribution of Dental Neglect questions

\begin{tabular}{|l|c|c|c|}
\hline Variable & Mean & $\begin{array}{c}\text { Std. Error } \\
\text { Mean }\end{array}$ & $\begin{array}{c}\text { Std. } \\
\text { Deviation }\end{array}$ \\
\hline Your child maintains his/her home dental care & 3.28 & .185 & 1.310 \\
\hline Your child receives the dental care he/she should & 3.36 & .130 & .921 \\
\hline Your child needs dental care, but you put it off & 2.32 & .175 & 1.236 \\
\hline Your child needs dental care, but he/she puts it off & 3.14 & .169 & 1.195 \\
\hline Your child brushes as well as he/she should & 3.62 & .171 & 1.210 \\
\hline $\begin{array}{l}\text { Your child controls between meal snacking as well as he/she } \\
\text { should }\end{array}$ & 2.50 & .160 & 1.129 \\
\hline Your child considers his/her dental health to be important & 2.70 & .222 & 1.568 \\
\hline Total Dental Neglect Score & 21.16 & .680 & 4.808 \\
\hline
\end{tabular}

Table 3. Mean distribution of Dental Neglect Score

\begin{tabular}{|l|c|c|c|c|c|}
\hline \multicolumn{2}{|l}{ Variable } & \multicolumn{1}{c}{ Mean } & \multicolumn{1}{c}{$\begin{array}{l}\text { Std. Error } \\
\text { Mean }\end{array}$} & $\begin{array}{l}\text { Std. } \\
\text { Deviation }\end{array}$ & \multicolumn{2}{c|}{$\begin{array}{c}\text { Chi square } \\
\text { value }\end{array}$} & P value \\
\hline Age & 8.88 & .508 & 3.589 & ---- & $0.02^{*}$ \\
\hline $\begin{array}{l}\text { Mother } \\
\text { Occupation }\end{array}$ & 1.90 & .239 & 1.693 & 96.101 & \\
\hline Father Occupation & 4.40 & .237 & 1.678 & 82.815 & $0.005^{*}$ \\
\hline Monthly Income & 6.58 & .457 & 3.233 & 1.1218 & $0.03^{*}$ \\
\hline Mother Education & 4.24 & .213 & 1.506 & 1.1243 & $0.02^{*}$ \\
\hline Father Education & 5.02 & .168 & 1.186 & 74.190 & $0.02^{*}$ \\
\hline $\begin{array}{l}\text { Socioeconomic } \\
\text { status }\end{array}$ & 15.84 & .790 & 5.589 & 2.7652 & $0.03^{*}$ \\
\hline
\end{tabular}

Table 4. Association of DNS with Demographic Variables (*statistically significant) 


\begin{tabular}{|c|c|c|c|c|c|}
\hline Variable & Mean & $\begin{array}{l}\text { Std. Error } \\
\text { Mean }\end{array}$ & $\begin{array}{c}\text { Std. } \\
\text { Deviation }\end{array}$ & $\begin{array}{c}\text { Chi square } \\
\text { value }\end{array}$ & P value \\
\hline DMFT & 2.08 & .367 & 2.594 & 1.342 & $0.01^{*}$ \\
\hline DMFS & 3.00 & .573 & 4.051 & 1.564 & $0.006^{*}$ \\
\hline Dmft & 2.40 & .334 & 2.365 & 88.844 & $0.07^{* *}$ \\
\hline Dmfs & 2.62 & .379 & 2.679 & 98.794 & $0.3^{* *}$ \\
\hline
\end{tabular}

Table 5. Association of DNS with caries status *statistically significant ** statistically non-significant)

\section{CONCLUSION}

It was concluded that:

- The socio-economic status plays an important role in the parent's knowledge and attitude regarding the dental care of their child.

- Higher DN causes increased dental caries.

- Parental education also plays an important role in maintaining child's good oral health.

\section{REFERENCES}

1. Bhatia KS et al., Characteristics of child dental neglect: A systematic review. J Dent.2014:42(3);229-39.

2. Harris J. Dental neglect in children. Paediatrics and Child health. 2016:26(11);47884.

3. Coolidge $\mathrm{T}$. the dental neglect scale in adolescents. BMC Oral Health. 2009:9(2).

4. Ramazani N. Child dental neglect. Int J High Risk Behav Addict. 2014; 3(4).

5. Mathur et al. dental neglect affecting oral health status in India. Int J Pediatr Res 2016: 2(1).

6. Sarkar P et al. Impact of Dental Neglect Scale on Oral Health Status Among Different Professionals in Indore City-A CrossSectional Study. J Clin Diag Res.2015:9(10);6770.
7. Gurunathan D, Shanmugaavel AK. Dental neglect among children in Chennai. J Indian Soc Pedod Prev Dent 2016;34:364-9.

8. Silver DH. A comparison of 3-year-olds' caries experience in 1973, 1981 and 1989 in a Hertfordshire town, related to family behaviour and social class. $\mathrm{Br}$ Dent $\mathrm{J}$ 1992;172:191-7.

9. Al Ghanim NA, Adenubi JO, Wyne AA, Khan NB. Caries prediction model in pre-school children in Riyadh, Saudi Arabia. Int J Paediatr Dent 1998;8:115-22.

10. Freeman R, Breistein B, McQueen A, Stewart $M$. The dental health status of five -year -old children in north and west Belfast. Community Dent Health 1997;14:253-7.

11. Williams NJ, Whittle JG, Gatrell AC. The relationship between socio-demographic characteristics and dental health knowledge and attitudes of parents with young children. Br Dent J 2002;193:651-4.

12. Thomson WM, Spencer AJ, Gaughwin A: Testing a child dental neglect scale in South Australia. Community Dent Oral Epidemiol. 1996, 24:351-56.

13. Ajagannanavar SL, Sequeira PS, Jain J, Battur H. Dental neglect among college going adolescents in Virajpet, India. J Indian Assoc Public Health Dent 2014;12:215-8.

\section{AUTHOR AFFILIATIONS:}

Post Graduate Student, Department of Pedodontics and Preventive Dentistry, BRS Dental College and Hospital Sultanpur, Barwala

Professor \& Head, Department of Pedodontics and Preventive Dentistry, BRS Dental College and Hospital Sultanpur, Barwala

Reader, Department of Pedodontics and Preventive Dentistry, BRS Dental College and Hospital Sultanpur, Barwala

Senior Lecturer, Department of Pedodontics and Preventive Dentistry, BRS Dental College and Hospital Sultanpur, Barwala

Private Practitioner, Saatvik Dental Care, Reasi, Jammu and Kashmir.

*Corresponding Author: Dr. Ishani Sharma, H.no-56, Vikas Nagar, Baltana, Zirakpur- 140603
For article enquiry/author contact details, e-mail at: editor.ihrj@gmail.com,editor@ihrjournal.com 